\title{
Modern Mouride Marabouts and their Young Disciples in Dakar
}

\author{
Kate Kingsbury University of Alberta
}

\begin{abstract}
This article provides an analysis of new religious Sufi Mouride movements in Senegal. In it, I analyse the charismatic leaders and their young disciples, elucidating that their interactive rapport forms the basis of the popularity of these movements. I demonstrate that young Dakarois have played a significant role in the regeneration of religious belief among the Mourides, and I posit that the leaders of these movements proffer a counter-discourse on leadership that provides an alternative to the gerontocratic models that characterise politics as well as traditional Mouride movements. I explain that the religious ontologies that new Mouride marabouts offer youth afford the latter the possibility to reconceptualise their identities, providing them with a modern pious paradigm that aligns with both their spiritual and physical needs.
\end{abstract}

Keywords: new religious movements, West Africa, Sufism, street youth, modernity

Résumé : Cet article analyse les nouveaux mouvements de la confrérie soufie des Mourides au Sénégal. Mon étude des dirigeants charismatiques et de leurs jeunes disciples indique que leur relation réciproque constitue le fondement de la popularité de ces mouvements. Je montre que les jeunes Dakarois ont grandement contribué à raviver la croyance religieuse chez les Mourides. Je maintiens que les dirigeants de ces mouvements proposent un contre-discours sur le pouvoir qui présente une alternative aux modèles gérontocratiques propres à la politique et aux mouvements traditionnels Mourides. Enfin, j'explique que les ontologies religieuses de ces nouveaux marabouts Mourides offrent aux jeunes la possibilité de repenser leur identité grâce à un modèle contemporain de piété qui répond à leurs besoins physiques et spirituels.

Mots clés : nouveaux mouvements religieux, Afrique de l'ouest, soufisme, jeunes de la rue, modernité
Qufi leader Modou Kara appeared with éclat before a crowd of cheering disciples. Garbed in a purplepinstripe grey suit, replete with matching trilby and hidden beneath Ray-Bans, Kara alighted from his Hummer. Over six hundred youth, many dressed in ripped jeans and Bob Marley T-shirts, pullulated toward him. "Can you see him?" a disciple interjected as I stood watching. "That is God." Bodyguards girded the marabout off, ensuring that devotees lurching toward Kara could not touch him. ${ }^{1}$

My first trip to Dakar was in 2005. Prior to my departure, my expectations were coloured by an expansive corpus of literature dating back to the 1960s. Cruise O'Brien (1971), Copans (1989) and Coulon (1981), among others, described marabouts dressed in their boubou,who dedicated their lives to studying sacred texts and teaching in schools, where disciples learned to recite the Qur'an. ${ }^{2}$ Their disciples, talibés, also donned the boubou, piously partaking in doctrinal lessons. Notwithstanding this, my first experience of a Mouride marabout jarred discordantly with the preconceptions I had formed.

I was told on Dakar's radio trottoir ${ }^{3}$ that two Mouride orders, belonging to Cheikh Bethio Thioune and Serigne Modou Kara, ${ }^{4}$ were gaining popularity. Their followers were primarily Dakarois youth. I realised that a new kind of Mouride leadership had emerged that prima facie showed little resemblance to that which I had read about. I noted that youth constituted a category unmentioned in the anthropological writings I had read.

In 2005, Khadim Mbacké's book Sufism and Religious Brotherhoods in Senegal was published. Mbacké augured that there was no future for Sufi orders in Senegal unless they reformed in line with other Islamic movements. Contrary to Mbacké's prognostication, 2005, the year I first went to Senegal, proved to be a critical juncture for the emergence of novel religious movements, influencing the inception of other orders across the Sufi spectrum. It heralded not the demise of 
Sufism but the burgeoning beginnings of a new form of maraboutic leadership.

This article focuses on the leaders, the marabouts, of these two movements, and their followers, talibés. My fieldwork was done between 2007 and 2009; I also returned to Senegal on numerous occasions thereafter, spending time with Kara's disciples and the Thiantacounes, Thioune's followers. In this article, I will explore how these marabouts and their practices differ from previous modes of religious leadership while maintaining continuity with an imagined past; and I will provide an analysis of the youngsters who continue to convert. To understand the rise of these new movements, both marabouts and disciples must be scrutinized. The marabout-talibé relationship is the fulcrum of Sufism's strength and longevity, and the basis upon which innovation takes place.

Although captivating leaders are primordial for movements' success, of equal importance are the "contributions of charismatic clientele" that form "the populist underpinnings of extraordinary power" (Cruise O'Brien and Coulon 1988, 13-14). It is myopic to concentrate on leaders of prophetic movements as charismatic figures responsible for their order's popularity. This would entail overlooking the leader-follower rapport, presuming it is "not reflexive but unidirectional - from the top downwards," negating the dialectical rapport and interactional underpinnings (Worsley 1957, xvi).

At its inception, Mouridiyya was founded upon the rejection of French authority. In contemporary Senegal, many youngsters were disillusioned with a gerontocratic state that they viewed as rapacious and disconnected from their quotidian realities, as well as the traditional Mouride leaders, who were not attuned to their modern lifestyles. The two Sufi leaders have crafted a counter-discourse about leadership, offering youth an alternative paradigm to that of gerontocratic, traditional Mouride and political leaders. They offer new ways of experiencing modernity that are simultaneously religious, redolent of a mythic Mouride past, and contemporary in orientation. It is the synergy between leaders who proffer novel forms of Mouridiyya and the support of young disciples that has led to the regeneration of Sufism. The movements that have emerged signal a shift in Mouride credo, marking a metamorphosis in a religion whose infinite mutability over time has ensured its success.

These new Mouride movements display parallels with the popular innovative and charismatic Pentecostal movements in Ghana and Nigeria, which authors such as Meyer (1998) and Lyons and Lyons (1987) have detailed. These new religious movements constitute inventive ontological models that allow for the reimagination and renegotiation of collective and individual life, as well as a way of coping with the effects of globalisation and modernity in the precarious flux of the post-colony.

\section{The Mourides}

During the colonial conquest of Senegal, the French dismantled the socio-cultural structures that had organised society, and the Senegalese found themselves with no raison d'être, no livelihood and no respected leaders. This disenfranchised populace was averse to the rule of white men and disenchanted by the leadership of puppet rulers. ${ }^{5}$ Cheikh Amadou Bamba Mbacké emerged as a religious visionary. ${ }^{6}$ Born and educated in a Qadir household to a father who was a marabout, Bamba would later become a Tijanni. However, during the colonial era, Bamba discerned the need to craft a new sort of Sufism that would meet Senegalese needs. He founded Mouridiyya in 1883 , adding a novel element to Sufi soteriology. Although he encouraged disciples to study the Qur'an, as was done in Tijani and Qadiri traditions, this was not mandatory for salvation. He suggested that illiterate disciples engage in agricultural labour as a form of worship and guarantee of salvation. ${ }^{7}$ Disciples were not remunerated financially but received bed and board. This practice perdures. To this day, Mouride devotees typically engage more readily in physical labour than those of other Sufi orders.

$A b$ ovo, Mouridiyya originated from the synergy of a charismatic marabout and the devotion of disciples. Bamba offered followers salvation and succour. His disciples' support bolstered his reputation, attracting more devotees. The peanuts they farmed allowed the order to amass wealth and power. The French authorities, alarmed by Bamba's influence, as he did not endorse their regime, exiled Bamba. ${ }^{8}$ This boosted his status among Senegalese, substantiating that he was not a minion of the colonial state. In absentia, his brothers took over affairs. In the entrepreneurial style that has come to characterise the Mourides, Cheikh Anta began dealing with relations with the colonial administration. This commenced an échange de services between marabouts and politicians that has become inherent to Senegal. Upon Bamba's return from exile, he agreed to cooperate with the French; despite this, Bamba's reputation as a holy visionary who defied colonial rule prevails. Since his death in 1927, he has been succeeded by marabouts from the same lineage. ${ }^{9}$

Mouride leaders are now immensely powerful and wealthy, in part from their farms and also from disciples' oblations; talibés regularly give cash donations (hadiya) to their marabouts in exchange for blessings. Since the colonial era, the Mouride faith has morphed to allineate with modern conditions. Much as Bamba adapted preexisting Sufi tenets to create a soteriology that coalesced 
with needs in the colony, in the post-colony, new Mouride leaders and disciples forge faith in novel fashions. Young people have chosen religious paradigms that resonate with their experiences of being young and Muslim post9/11 (Masquelier and Soares 2016, 173).

My fieldwork involved spending time with Dakarois youth to gain an understanding of their world views. My informants spoke about their spiritual motivations for conversion and, often heartbreakingly, about the dreadful difficulties they had to deal with, difficulties that had diminished since their conversion to Kara's or Thioune's order. They felt certain that through devotion to their marabout, a direct channel to Allah, their salvation would be ensured. Bamba faced numerous years of hardship when he was exiled by the French; in Mouride mythology, Bamba's banishment has been couched in mystical terms as an event that led to spiritual illumination (Kingsbury 2014, 97). Many young disciples drew parallels between Bamba's vicissitudes and their own. Mame Mareme told me that like Bamba, she and her husband, Ousmane, had faced ordeals, but they knew their devoutness would be recompensed: "We know that the strength of the Mourides is that they are destined for paradise." Ousmane interjected: "A miracle will occur. We have no money, nor possessions, but we don't care because we know that Serigne Kara is great. Those who follow him will be rewarded."

Most disciples aware of injustices idealise marabouts as a manifestation of Allah, a living saint who can alter their circumstances. They seek an eidolon whose message meshes with their immediate needs and whose telos matches their aspirations for a better world. Janson $(2014,20)$ states, with regards to Tablighi youth of the Gambia, that the desire to embrace both religion and "the search for modernity" has its locus in the "strong belief in the ability to correct the world." For many youth, Kara's order offers a means to reformulate a general order of existence (Geertz 1973), as well as a political voice where they may confront the state through spiritually sanctioned performances. Babou, a disciple of Kara told me that

young men have lost perspective; they can't find women to marry, they are influenced by rap artists who promote violence, they are unemployed, many of them are trying to escape on pirogues to Barcelona. ${ }^{10}$ Some of the younger generations don't want anything to do with the old-style marabouts. Serigne Kara is different. Young people respect him. He is doing something positive, politics founded on a spiritual message and a modern vision. (see Kingsbury 2014, 261)

New Mouride movements comprise a reaction to young Dakarois' onerous circumstances as they seek to live piously in a world characterised by modernisation, capitalism and delayed adulthood. Alfa, Thioune's talibé, invited me to visit his home to meet his family. He lived in a destitute neighbourhood. The compound where he lived was collapsing. The rooms surrounded a squalid central yard where cooking was done on an iron grate placed over some logs. Alfa's father greeted me, scarcely able to stand, with a bottle of liquor in hand. Embarrassed, Alfa led me into a bare room that contained nothing but a grimy mattress on the floor, where I was invited to sit down. Cockroaches scuttled across the filthy walls, and a baby wailed incessantly.

Alfa's family barely had enough money to eat one meal a day. He told me,

I am learning to be a carpenter. Cheikh Bethio told me that I must learn a trade to earn my way. I was unemployed but met disciples at the thiants who offered me work. I will need a wife, when I do Cheikh Bethio will help me find a righteous woman. It won't be hard for me the way it is hard for some young men. I didn't feel the spirit of Bamba until I found Cheikh Bethio. The way he educates us teaches me to be a good man. No matter what I go through today, Cheikh Bethio shows me how to get closer to God. I will go to heaven and find peace. (see Kingsbury 2014, 269)

Soares and Otayek $(2007,6)$ have described how there has been a "superficial and alarmist" focus on the rise of reformist groups. Islamic reformist movements that emphasise Puritanism and scripture may have attracted converts abroad; nevertheless, there are few Dakarois youngsters who adhere to such ideologies. Most of the youth I met struggled daily to find a meal and had scant education. A faith based on knowledge of sacred writ and abnegation of worldly goods was not germane. What reformists would deem as "impure" forms of devotion, such as idolatry and magical modes of worship, remain cardinal to new Mouride movements.

Youth in Senegal, as across the rest of the continent, are excluded from socio-economic and political spaces. They are exposed to a global flow of images of material goods and luxurious lifestyles, which they may consume visually but are unable to access physically. Youth thus seek new spaces of inclusion in pious paradigms that synchronise not only with their vision of modernity but also with their needs and dreams.

Mouride disciples had varying motivations for conversion. Some converts stated that they were drawn to a movement because of its spiritual appeal. Other talibés claimed to be attracted to the same movement owing to practical benefits and this-worldly reasons. For example, some of Thioune's disciples extolled the marabout for 
his pedagogical speeches that emphasised a righteous modus vivendi, whereas others praised his approach to marriage. Kara's disciples stated that the demands of superannuated marabouts who followed "traditional" ways, requiring that their talibés observe the five daily prayers and attend Quranic school, had no propinquity with their lifestyles. Some of Kara's disciples chose to drink beer, disregarded Ramadan or engaged in other behaviours that might be considered antithetical to the practice of Islam by many Muslims. Yet these were tolerated by Kara's laissez-faire religious doctrine. Numerous disciples also lauded Kara for his modernising projects to develop Senegal's economy according to Mouride tenets.

Some Mourides and other Muslims, of the older generation in particular, vilified these Mourides for perverting religious discourse. As Berliner (2005, 578) points out in his work on religious transmission, when academics favour the testimonies of elders, promoting their animadversions as per the divergent ways in which young Muslims reconfigure faith, they "neglect the supporting and active role of young people within society . . . as active agents in regenerating older ... religious practices." To ignore or denigrate any one form of Islamic belief or behaviour on the basis that it is not "pure" or "true" Islam would be erroneous (El-Zein 1977). The manifold, dynamic multiplicity of often contrasting and contradictory forms of Islam described in this article confirms that there are multitudinous ways of being Muslim. Islamic belief and practice are not homogeneous, bounded and immutable but protean, polymorphic and dynamic. As anthropologists, our priority should be to represent Islam, and other religions, from multitudinous viewpoints, taking into consideration the voice not only of elders or authority figures but also of women and youth.

\section{Youth and Politics in Dakar}

Over the last two decades, the people of the African continent have faced armed conflict and political upheavals, as well as the HIV/AIDS pandemic, in addition to increasing unemployment and economic problems due to reforms associated with neoliberalism and free-market conditions. Disquisitions focusing on the West have linked being young to a gratifying status of amusement enjoyed $a d$ arbitrium (Christiansen, Utas and Vigh 2006, 34-35). In Africa, youth does not carry such romantic ideograms; it is often a space of liminality where postponed access to adulthood represents entrapment, even social death. Honwana (2012) refers to waithood as an interminable adolescence that is not pro tempore but the status quo.

Youth in Africa must find strategies to deal with such difficulties. Much as young people are "positioned in society," they also "seek to position themselves"
(Christiansen, Utas and Vigh 2006, 12). They choreograph their own local navigational strategies. Across the globe, they are dynamic agents in the reimagination, regeneration and remodelling of cultural and religious practices.

Youth in Africa have been conceptually burdened with antipodal labels as "vanguards" or "vandals" (Abbink and van Kessel 2005) or "makers and breakers" (Honwana and De Boeck 2005). They have been ostracised from politics. Nevertheless, in the independence era, youth were seen as the hope of African states. Léopold Senghor, the first president of Senegal, organised urban youth for state projects. Eventually, violent riots erupted: youth refused to be harnessed for schemes in which they had no voice. The state quelled this tsunami through the politics of repression, muffling the voices of the young. Senegal's second president, Abdou Diouf (1996, 239), denigrated youth as "the accursed share of Senegalese society," blaming their outcries on "une crise de valeurs," a crisis in ethics. Since emancipation from the colonialists, it has been a case of plus ça change, plus c'est la même chose. Malfeasance is endemic to the state. Young Dakarois are tired of the discourses of leaders who make grand promises and fail to deliver. They see themselves as paying the cost.

The Senegalese economy has struggled since an economic crisis that commenced in the 1970s. It was succeeded by the groundnut crisis of the $1980 \mathrm{~s}$ and $1990 \mathrm{~s}$, the devaluation of the CFA in 1994, the implementation of structural adjustment and growing privatisation. ${ }^{11}$ This has led to rising social inequality. The number of unemployed and impoverished youth has risen as economic possibilities have dwindled. I was appalled at how many homeless youth wandered the streets. Social services for such youth are unavailable.

Many Senegalese presumed that Wade was elected thanks to millions of Mouride votes. In an échange de services well-documented by Cruise O'Brien (2003), politicians offer capital and goods to Mouride and other marabouts, who in turn ensure their disciples vote for them. ${ }^{12}$ This may at first seem paradoxical, because religious notions, such as that of Mouride "purity," are often contrasted with the satanic powers beyond - namely, the government. Such "symbolic confrontations" are but theatrics masking the reality of a "partial accommodation" (Cruise O'Brien 2003, 5). Thioune, one of the leaders of the new Mouride movements, was a well-known conduit between the government and the Mourides. Straddling politics and religion, Thioune ensured that disciples' support for the regime was maintained; in return, he received favours from the state. ${ }^{13}$

Wade's election initially ushered in an era of hope. Nevertheless, his popularity waned with celerity due 
to the persistence of problems experienced under the previous regime. Questions were posed about Wade's use of power in Senegal (Coulibaly 2003; Gaye 2010; Seck 2005; U.S. Department of State 2007, 469), while some suggested chicanery in his ascent to power. ${ }^{14}$

Notwithstanding the fact that wealth, in West Africa, is often seen "as the external sign of internal virtue" and may be "exhibited as such by politicians" (Lonsdale 1987, 347 ), it can also cause the downfall of a politician. In Senegal, as elsewhere, a man of means must redistribute the shares of his spoils or be considered corrupt. Many youth, living in abject poverty, speculated that Wade peculated for personal gain.

The press continuously criticised Wade. L'Observateur - a Senegalese newspaper with a large readership noted in September 2007, one week after the rise in the prices of electricity and food, that Wade purchased jeeps for all officials and a stretch limousine for himself (L'Observateur, 6 November 2007). ${ }^{15}$ Wade named his son Karim as Personal Advisor to the President of the Republic in 2002. Advocates stated that Karim's "training" would endue him with the skills needed to be a future leader. He was put in charge of Génération du Concret (Generation of the Concrete [GDC]), a project for the development of Dakar in preparation for the Organisation of the Islamic Conference (OIC). GDC was initially applauded, but in practice, most GDC projects proved to be utter failures. ${ }^{16}$ In a play on words, Génération du Concret was renamed Génération que les Cons ont Créée by local wits. This title involves a play on words that cannot be translated to English verbatim to the same comedic effect, but it literally means "generation that the idiots created." Youth recounted how GDC funds were invested in rich areas while they were "unable to afford rice or fish" themselves (Chatterji and Gangopadhyay 2009, 270). Karim Wade eventually had to face questioning in court about his unscrupulous use of the OIC budget (L'Observateur Jeudi, 14 February 2008). ${ }^{17}$

Upon the realisation that it would have no tangible benefits for them, GDC was vituperated by the youth. The scheme reiterated the ostracisation that Diouf had imposed: treating youth on the street as encombrements humains (human congestion). GDC implemented various measures to "clean" Dakar's streets. These involved the removal of the homeless and informal street vendors, many of whom were Dakarois youth. This fomented violent demonstrations. I witnessed rioters set light to tires doused with petrol, smash police vehicles and loot government offices; meanwhile, police also broke up a march against rising living costs by beating participants with truncheons and suffocating them with tear gas (Thomson and Tattersall 2007). With "proper" jobs hard to come by, young people become involved in numerous activities in order to subsist. Many of these youth work in the informal economies, selling miscellaneous items at traffic lights. Others operate in tourist spots, selling objets d'art. Nonetheless, competition is high, prices are low, and it is difficult to make ends meet. Some individuals succumb to sex work, drug dealing and other illegal activities, subsequently having few means of reintegrating. Youth engagement with violence, sex work and other illegal activities "delegitimises their politics," further entrenching "the hegemony of dominant elders" (Kagwanja 2004, 105).

Young people are "poorly equipped to make their opposition effective" (Cruise O'Brien 2003, 55). Joining a Mouride movement with a political message such as Kara's may provide answers to the quest for meaningful existence, but it may also be viewed as "an alternative circuit of meaning and dignity after the failure of political engagement" (Argenti and de Waal 2002, 138). Given that crises in Dakar are oft experienced through "a metaphysics of disorder" (Comaroff and Comaroff 2006, 273), a spiritual map may prove a means by which to imagine the restoration of external and internal order.

\section{Mondaine Modern Marabouts}

The first two generations of marabouts, descended from Bamba, continue to behave according to traditional Sufi tenets. These marabouts are known as scholars of Islam; they are fluent in Arabic and devote much time to studying the Qur'an and qas'aid, they practise the dhikr, ${ }^{18}$ and so forth. They dress in what are deemed traditional garments. ${ }^{19}$ Diop $(2000,167)$ has described the "apparition of a new generation of marabouts, who unlike other Sufi leaders, are more preoccupied with commerce and politics" than with religion (author's translation). ${ }^{20}$ While their predecessors might have been surreptitiously active in politics and commerce behind closed doors, their focus in public was on spirituality. The new marabouts brazenly involve themselves in business and politics: Kara leads a political party.

These new marabouts do not prioritise the usual path for a marabout. They do not insist that their disciples study the Qur'an, they may not study it themselves, and they do not emphasise the learning of Arabic - Kara himself cannot speak Arabic. They do not always attire themselves in the boubou - Kara frequently appears in ostentatious western designer clothes. Furthermore, Kara and Thioune have no qualms about living in numerous visibly sumptuous abodes, as opposed to maintaining the appearance of austerity. ${ }^{21}$ These leaders appeal to the youth, as they offer a spiritual discourse that embraces modernity, thereby creating new ways of being young and Muslim. 
Both marabouts have attracted large groups of disciples under the age of 30. Kara and Thioune play with different ways of imagining what it means to be a Mouride and Muslim. Although no enmity exists between the two, there is no friendship either. Kara is revered by youth as if he were a deity. By virtue of his blood ties with Bamba - he is the grandson of Bamba's elder brother Kara is granted a hallowed status. Blood links have for centuries been involved in images relating to perduring social relations, although misconduct may weaken one's claim to status. Hence, Wade's son, despite his blood links to his father, has been deemed unfit by many citizens to gain state power, whereas in Kara's case, blood links ensure that he is revered.

Wade's opulent displays were often treated as signs of a power sullied by corruption. Kara and Thioune have accrued great wealth, acquired through business and disciples' gifts, yet this has not been stigmatised by followers. These are signs that they possess great spiritual blessings known as baraka (described in more detail below). Christians may critique these marabouts, and Sufis from other orders, even if they disapprove, admit that these leaders enjoy immense baraka.

Mouride marabouts only air their reservations about innovatory marabouts behind closed doors in order to present a coherent external image of the order; it is not in their interests to make public their misgivings. They are aware that by openly criticising maraboutic behaviour, the ideal of the Mouride family of leaders may be fractured. Even if certain behaviours are not condoned, at the same time, any power amassed by one marabout contributes to the powerful image of the whole. Thioune and Kara, even if diverging from what many Mouride Cheikhs deem appropriate praxis, still contribute to the mystique of Mouride spiritual puissance.

Although numerous Senegalese are critical of these new marabouts, they do not judge them as harshly as corrupt politicians. Even if the accumulation of power and possession of wealth in politics in the post-colony is expressed through idioms of consumption, when poverty prevails, political leaders are deemed to be ineffectual and prone to excess. Such accumulation is viewed as the outcome of a zero-sum game, in which the populace loses out. The power belonging to Sufi leaders is of a different ilk. This mastery is synonymous with baraka, which Hill $(2007,25)$ glosses as blessing. Baraka is manifested externally as wealth and power; yet within Mouride metaphysics, one cannot say that religious knowledge or authority precedes power or wealth, or vice versa: they are mutually constitutive. Furthermore, baraka cannot be reduced "to a social construct such as symbolic capital"; rather, it must be seen as a "connection to the Divine through a doorway" (Hill 2007, 333).

A marabout's possession of baraka is not monopolistic. Although the marabout represents the concentration of baraka in "a single pole," he simultaneously opens up "multiple avenues to this pole through mystical presence" (Hill 2007, 26). Baraka is not hoarded by leaders but flows out from them to disciples in "sacred circuits" that "create forms of value that are not determined by the market" (Buggenhagen 2012, 62). The only way for disciples to acquire baraka is through their relation with their marabout. Blessings are vital to the success of any activity a Sufi undertakes.

Baraka is supposedly strongest closest to the source. Bamba was the superlative source. As a grandson of Bamba's brother, Kara's baraka is deemed very powerful; furthermore, Kara's neoteric approach makes him unique. He targets youth living at the margins of society; he is renowned for preaching in prisons and dangerous slums, going to places no other marabout has dared to go to before. The Serigne's "good works" constitute a cogent sign of his exceptional baraka. His discourse on leadership is contradistinct from that of the older generation of marabouts, or statesmen. Although Kara makes profits from the groundnuts cultivated by his disciples' free labour, many Senegalese extol him for recruiting individuals involved in illegal activities and reforming them. No other marabout has ever done this. On farms, disciples receive spiritual instruction, as well as free food, medication and clothing. Since unemployment is high in Senegal, and uneducated youths have no social security to turn to, many see working on Kara's daaras ${ }^{22}$ as "une profession masquée," in the sense that this work is likened to a covert mode of employment and hence a means of survival. ${ }^{23}$

By virtue of blood ties, Kara is perceived as holy - as a man embodying "tradition" - yet his modern outlook is visible in his sartorial style. He is often photographed in designer garb and featured in popular weekend magazines, where he speaks of everything from football to women. He has also launched his own political party. Kara defines himself and his projects in opposition to statesmen and failed state plans. No other marabout has ever conducted himself in such a manner. Blurring distinctions between modern and traditional, material and divine, Kara interlocks a "combination of several temporalities" (Mbembe 2001, 15). He exploits the message of Mouridiyya, seen as a "traditional" spiritual force, to spread his modern political message.

Thioune, much like Kara, has established himself as a "big man," but through dissimilar methods. Thioune hails from a noble, but not holy, lineage and has an 
administrative background. For many years, he was involved in civil service to the Senegalese state. After several decades of dedication to Serigne Saliou, Khalifa General, ${ }^{24}$ the Serigne bestowed upon Thioune the title of Cheikh. The role of marabout is hereditary: Mouride leaders always hail from Bamba's bloodline. Thioune was the first individual to be conferred the designation. Since he acquired his baraka from Bamba's last son, his disciples believe he is supremely special.

Rumours from radio trottoir suggest that Thioune was made Cheikh ex officio. Thioune's secure networks within the state administration made him useful to Serigne Saliou, allowing him to grant special services. Because of his administrative background as a civil servant, Thioune has chosen to present himself using what is seen by Mourides as traditional comportment. Thioune is nevertheless protean, "straddling between administration and business" (Bayart 1989, 70-71) and religious duties.

Yet events occurring after Wade's departure from office have cast a sombre shadow over the marabout, although they seem not to have lessened his number of adherents. ${ }^{25}$ Thioune had a close rapport with Wade, who in an échange de services protected the marabout, who likewise did favours for him. Wade lost the presidency to Macky Sall in May 2012. In April of the same year, Thioune was convicted for the murder of two men. The men were allegedly beaten to death and inhumed alive in a hole by Thioune's disciples. They were purportedly following his instructions. This occurred amid controversy around his marriage to a seventh wife. ${ }^{26}$

Thioune was jailed in the most comfortable cell at Thiès penitentiary. He had given a large donation to the prison system on the condition that renovations would be undertaken. Thioune and Sall were subsequently on bad terms. Recently, however, Thioune has distanced himself from Wade and undertaken a rapprochement with Sall (see Dakarmidi 2017). Additionally, Serigne Saliou died in 2007 and has since been replaced. Once again, Thioune has been adept at forging ties with the new Khalifa. ${ }^{27}$

At the time of my fieldwork, Thioune was organising weekly thiants. These were the first Mouride rites of their kind, and they featured huge gratis feasts. Some attended just for the prospect of a free meal. Mass marriages were also conducted, a practice never before carried out among the Mourides. Couples were able to marry without paying bridewealth. This is most unusual, as bridewealth is indispensable. Often, marriages were arranged by the Cheikh's entourage. For many of Thioune's disciples, the prospect of foregoing bridewealth was extremely attractive; it is nowadays incompatible with low incomes, thereby posing an obstacle to marriage. Music and gentle dancing also occurred, the latter being forbidden in all other Mouride rituals.

During thiants, Thioune cited the piety and grandeur of Serigne Saliou. It was in his interest to do so, since by promoting Serigne Saliou as sacrosanct, Thioune's "cheikhood" was warranted. In contradistinction to Kara, who promotes novel political ideologies based on Mouride theology, Thioune's performances have had as their goal to uphold what is imagined as Mouride tradition. Kara, since he originated directly from a bloodline imagined as holy, has had no need to fortify the latter element. Thioune, a man who previously worked as a state official, has chosen performances that dampen his background in favour of those that imply ideals of authenticity.

Thioune has established himself as a big man, distributing food to many dependants. At the thiants I witnessed, over a thousand disciples feasted on victuals. In Senegal, people are often unable to afford to eat more than one meal daily. Food, especially in large amounts, is a luxury. Brandewie $(1971,199)$ points out that "a very important function of the big man is the fair distribution of food . . . Sharing and distributing are concomitants of every ceremony."

Gastronomic performances across societies have long constituted a space within which to demonstrate hierarchies of power. Disciples told me that thiants represented the highest form of prayer, whereby through the act of sacrificing "bêtes de toute sortes" (animals of all ilk), those present could access a celestial plane. Indeed, in this context, commensality, which defines both one's lifestyle and processes of subjectivation, is an act possessing a singular power that is, as Bayart (1989) argues, constitutive of the "politics of the belly."

Although funds provided by disciples have made Thioune rich, he was perceived by disciples as redistributing riches back to the community by offering food and baraka. In 2016, he provided five thousand cows for sacrifice and consumption by disciples at festivities in the holy city of Touba (see Dakaractu 2016). I was told by disciples that wealthy talibés gifted him cars and houses but that he redistributed these to other disciples. As Mauss (1969) posited, relationships are mediated and created through gift exchange. Yet what circulates are not just gifts but tokens creating networks of "indebtedness and subordination" (Mbembe 1992, 25). Such performances are not selfless acts, although they may well be perceived as such.

These two marabouts have fashioned unique contemporary ways of performing Mouridiyya, offering new religious avenues and "ways of being" Mouride for youth in Dakar. Kara's novel political message and practice of recruiting talibés from jails and the margins 
of society, and Thioune's thiants, which comprise a completely new rite, are striking examples. Such innovative approaches have captivated youth. Thioune and Kara cannot be analysed as figures in isolation. Their success has been bestowed by the youth of Dakar, who, disillusioned with political leaders and disenchanted with more traditional religious figures, have turned to modern marabouts, whose messages align with their lifestyles and desiderata.

\section{Kara's Converts}

My initial encounter with Kara's disciples was at an event the marabout gave to promote his political party. It was in July and 45 degrees Celsius. Six hundred disciples waited to catch a glimpse of their marabout. Most deemed him an omnipotent superbeing. While the youth stood in the burning sun chanting the name Kara, I had time to talk with many.

Kara has recruited his young disciples from the lowest echelons of society. He has trained some to form a militia that the local police fear, hence his militaristic sobriquet, "Le Général." For some non-Mourides, Kara's disciples were ignominious rabble. Kara's vespertinal religious parties often had to be broken up by the police following drunken brawling. The marabout acquired notoriety due to controversial behaviour, such as having driven over disciples in his Hummer; Kara has denied these allegations. Disciples believed that Kara could not injure them due to his puissant baraka.

Kara set up the first Mouride political party, the Parti pour la Vérité et le Développement (Party for Truth and Development; the PVD). Kara's project Génération pour la Vérite (Generation for the Truth) was supposedly an underhand critique of President Wade's unsuccessful Génération du Concret. Since its inception, the PVD has gained sway, acquiring seats in the assembly. Kara supposedly wanted to run for president, but the Mbacké family advised against it. ${ }^{28}$

Most of the disciples told me that they came from impoverished backgrounds. Some had parents who were disciples of the older generations of Mouride marabouts or who belonged to other Sufi orders. Many did not deem their children's allegiance to Kara problematic. Furthermore, numerous youngsters recounted that they had little contact with their parents; many explained that their parents were dead or lived far away.

When Cheikh ${ }^{29}$ was 16 years old, he told me, he ran away from his family, who lived in rural Senegal. He was constantly beaten by his stepmother and stepbrothers. He went to Dakar, hoping to find a better life. When he arrived, he could not find legitimate work and soon became involved in criminal activities to make ends meet, eventually ending up in jail. Cheikh explained that he was in a penal camp for juvenile delinquents where Kara came to talk to the inmates. Cheikh was entranced by the presence of a higher deity and converted. Once Cheikh left the detention camp, he travelled to Kara's farm in Darou Al Mouhty (often referred to as Darou Mouhty or simply Darou) to labour for his marabout. He lived there for nearly a year and became a changed person, he said. Kara had set up workshops for disciples to teach other followers useful skill sets; Cheikh trained as a carpenter. When he returned to Dakar, he began making simple furniture to earn a living in a righteous fashion and to provide hadiya to Kara. ${ }^{30}$

Thierno sat on the curb smoking cigarettes, attempting to seek shelter from the burning sun in the paltry shadow of a wispy tree. He came from a deprived background; his options had been limited by his minimal education and his inability to find a job, as well as a lack of family support. Thierno's testimony demonstrates how easy it is for youth with few means to become part of the many criminal gangs. Thierno, after years of hardship, divorced from mainstream society and with no options to reintegrate, met Kara, whose religious message offered spiritual salvation along with practical aspects that supplied constructive solutions to real problems. As Geertz $(1973,104)$ suggests, religion may offer adherents the "ability to comprehend the world and the ability to endure it" - in this case quite literally.

Thierno related the following to me:

I never went to school. I never learned to read and write. My aunt was looking after her children, she had six, plus me. I started peddling objects in the street from age seven. When I turned eight, my uncle left my aunt. She now had even less money. She told me to leave because she couldn't afford me.

I was on the street with no money, no home. The first week was the hardest time of my life. I was hungry, dirty and tired. I did not know what to do. I made friends with kids who were part of a gang. They made me pass some tests to join. These involved stealing things for the leader. In the gang we learned from each other how to steal and ways of getting by, things I knew in my heart were bad.

When we grew older, we got involved with port stuff. Big drug connections are there. Some of the boys would sell drugs. We did whatever was available, making enough for food, and so we could enjoy drinking and drugs, to forget what we felt inside. We were a gang of about 30 boys. We would often get into trouble. Many of my friends got caught by the police. One of my friends even died from police brutality. 
Thierno continued:

Then Le Général started visiting my neighbourhood. He made me look into God's eyes. All the kids were talking about Serigne Kara. I decided to see for myself. Straightaway I listened to this marabout. It was as if he knew my problems, all the things I had done, and he wanted to help. He did not ask me for hadiya. He was talking to me like the father I never had, but he was no father, he was God. I asked him what I should do because I could not continue with street life. He told me to go and work in Darou [at Kara's farm]. I went there; he even gave me money for the bus.

I worked in his fields for two years. I didn't need to worry about food, where to sleep, if someone would try to beat me or if the police would catch me. Everything was given to us. All we had to do was work and respect the word of Bamba. I knew this was helping me to become a good person. I met a new family, brothers who looked after me and each other, teaching us the righteous ways of God.

Thierno went on to conclude, "Later Serigne Kara helped me find work. He gave me a job in a tam-tam factory. I was doing bad things to get by and he gave me a new start and a new family."

Most of Kara's disciples told similar stories, yet numerous followers also joined for political reasons. I met Babou at a cultural complex where he worked as a security guard. Babou had a good education; nevertheless, he had few opportunities. Babou vilified the Senegalese statesmen, blaming them for the problems he and his family had faced, as well as those he had observed in society. He attributed his lack of success with women to their limited opportunities, which he saw as the reason for their venal approaches toward marriage. Babou described how joining Kara's order had given him hope for a better political future. He saw in Kara an alternative leader, one whose religious background ensured the truth of his claims. The order provided a sense of communitas and a place where he could speak of politics through a sacred lexicon.

Babou stated,

I have turned to Kara not only due to his Godliness but also as he is the first marabout to set up a political group, the only hope for the nation. The PVD will enable more concrete actions to take place. I completed university, but upon completion of my degree I found it impossible to get a decent job. This is the fault of the government. I have not married as I cannot properly support a family. Young people here have no future, so they lose themselves to crime, violence, drugs and prostitution.
Babou echoes the sentiments of young people across the continent whose voices are not heard and for whom adulthood is delayed. For young men such as Babou, it "is impossible ... to attain the role and position which is prescribed and expected of them" (Christiansen, Utas and Vigh 2006, 38).

Babou related how grateful he was to have found Kara's order, where he could assert his views and mobilise with others in the hope for a better future. As Babou's testimony demonstrates, young people are vanguards, active in self-authoring new spaces influencing local society and its political forms.

Notably, I was told the same allegory in varying forms by different youngsters. This related the story of youth crossing to Spain and the gamble they took for a better life. Diarra recounted another variation of this tale in the following story:

Ibra has nothing - no money, no food, nowhere to live. He sees a massive pile of money in the middle of a motorway. If Ibra could grab it, he would be able to afford to live comfortably for the rest of his life. Yet he also sees a steady stream of traffic. Ibra runs into the road to snatch that money, but, as he does so, a juggernaut heaves toward him. Despite odds that are unfavourable, Ibra risks life and limb to obtain this money.

This story is a parable for Senegalese youth. Over a decade later, following my very first trip to Senegal, it remains pertinent; it illustrates young people's meagre options. Some youngsters decide that they will not take the chance, Diarra told me. Yet others, whose lives are too unbearable, risk being maimed or killed to obtain money. That, Diarra recounted, is the story of youth who go on the pirogues to Spain. ${ }^{31}$ Many never arrive in Spain: they drown or are eaten by sharks. Diarra explained how he nearly took that risk. Before meeting Kara, he was considering a nefarious scheme to make money to pay for his crossing. Luckily, he says, Kara found him and saved him. I asked Diarra how I would be able to recognise Kara. He replied, "he does not look like an ordinary man; he is God."

I could barely hear Diarra as luxury vehicles began arriving at the marquee. The disciples were ecstatic. These arrivals heralded Kara's entrance. The security guards became exceptionally vigilant. Kara emerged from his gold-plated Hummer surrounded by bodyguards. The crowd had to be controlled. The marabout waved to his disciples, who rushed toward him. Kara appeared before his disciples for less than two minutes, walking on a pathway, hewed through the crowd by security personnel. He then disappeared into the marquee to 
deliver a speech about the PVD. Many disciples tried to follow Kara into the marquee, but all were denied access.

\section{Thioune's Thiant}

Thioune organises thiants every Saturday. When attending his thiants, I noticed that his converts were between the ages of 13 and 27. As well, Thioune has a large number of female talibés: the Cheikh's practices are more inclusive of women than Kara's. Cheikh Thioune uses his thiants as a stage to demonstrate his charismatic persona, for it is said that his unique spirituality gave rise to the Khalifa naming him Cheikh. Thioune appeals to youth who are not only concerned with spiritual salvation but also committed to making prosperous livelihoods.

Thioune is known for emphasising didactic religious teachings at his thiants. Some youth related how they used to spend their weekends in nightclubs, drinking and chasing women. Exchanging the discotheque for the thiant, they felt, had improved the quality of their lives, both spiritually and practically.

The thiants feature mass marriages. Generally, Mourides have private weddings where the groom must pay an expensive dowry to his future wife's family, and a lavish wedding must be provided by the bride's family. This has rendered marriage an unaffordable luxury for many. Thioune has created a sui generis Mouride solution that for some Sufis is sacrilegious.

I arrived around midnight. Many devotees were helping to prepare the night's events. Disciples were erecting a long tent on the pavement. Behind, in one of the Cheikh's properties, female disciples prepared bowls of food known as toufés. While waiting for the event to begin, I spoke to disciples. Fatou worked in a Lebanese bakery. She dreamt of marrying but found it difficult to meet an eligible man. Those suitable were older than her and had several wives. She did not want to be a second or third wife - they often have few rights and must live with their mothers-in-law and work for them, she explained. Fatou stated that many young men had left to live overseas and send remittances to their families; often the young men left behind did not have the means to pay bride prices. Fatou's cousin Diewo took her to a thiant where she briefly spoke to the Cheikh. She felt soothed by his spiritual presence. The Cheikh assured Fatou that he would find a good husband for her. Fatou converted thereafter. Within a few months, a member of the Cheikh's entourage suggested a husband. Fatou got married at the thiant and now lives with her husband, who supports her family.

Shortly after 1:00 a.m. around 1,500 people arrived; they took their places in the tent. Minutes later, a chauffeur-driven luxury SUV appeared. Thioune descended dressed in an ornate mauve boubou. He took his place on his throne at the front of the tent. Disciples began forming an extensive queue for the honour of receiving the Cheikh's blessing and to hand him their zakat (cash donations). In three hours, over seven hundred disciples approached Thioune for his baraka. He spat on each one, and they rubbed his saliva on their faces.

Ibou related how he was ashamed to have been involved in the sex trade. He confessed that it took him a long time to disentangle himself, yet he felt that he had no alternative solution at the time. Ibou confided to me that before he joined Thioune's order, he had had sexual relations with toubabs to earn his living..$^{32}$ Ibou worked in the informal sex trade from age 17 to 25 :

If I couldn't find a white woman in Dakar, I would go to beach resorts to find white women. My sister was doing the same with the old white men. Some guy friends would even go to Gorée to find toubab men who liked boys.

Sex work may at first blush appear to allow youth a chance to increase their earnings and use their agency to gain independence from families and limited possibilities (Chernoff 2003). Notwithstanding, we must be wary of advocating agency and autonomy in such "morally ambiguous contexts," given the possibly severe negative consequences (Cole 2007, 88). The dangers for sex workers, who become isolated and entrenched in the profession, consist of downward social mobility, unwanted pregnancies and serious health issues such as HIV/AIDS.

Ibou, after attending a few thiants, began to form a network with fellow disciples who found him legitimate work. Thioune's words evoked in Ibou what Geertz (1973, 95) has described as "moods and motivations." These, he states, caused him to reflect upon his behaviour and abandon it in favour of a more pious modus vivendi. The moods and motivations experienced by Ibou "induced by rituals and symbols reflect back to colour the individual's conception of the . . . world"; even beyond rituals, "the framework of meaning" remains intact (Geertz 1973, 95). Ibou found new ways of living in his world both at a cognitive and material level. He felt that he had found a spiritual haven and means to absolve his guilt.

\section{Conclusion}

Mouridiyya has always derived from a dynamic synergy between marabouts and talibés. If Mouridiyya continues to flourish, it is because of its creative capacity to reinvent itself through the ongoing spiritual synergies of leaders and disciples - to align with l'air du temps. 
Many youth in Senegal face limited options in a harsh environment that thwarts their access to adulthood, the political arena and other opportunities. They seek leaders relevant to their modus vivendi. Thioune and Kara have crafted a counter-discourse about leadership that juxtaposes with that of gerontocratic state and traditional religious leaders. They offer a novel form of Mouridiyya that meshes with the physical and metaphysical needs of youth. The support of young people has led these movements to flourish, regenerating Mouridiyya and creating new ways of being young and Muslim in the post-colony.

\section{Notes}

1 Marabout is the appellation for a Muslim religious leader in West Africa. Typically, the marabout is also a teacher, whose pedagogic instruction is of a religious nature, at the centre of which is the study and recitation by heart of the Qur'an.

2 A boubou is a long, flowing, loose-fitting robe sewn from one piece of cloth; it is usually worn by men with a matching pair of loose trousers and by women with a coordinating pagne or skirt and head-tie. Nowadays in Senegal, the boubou is largely worn for formal events, as western fashions have become more prevalent. However, traditional marabouts usually garb themselves in the boubou.

3 Literally pavement radio; the term designates informal communications networks used to disseminate information.

4 The title of Serigne (Seriñ), in Wolof, Senegal's principal language, has the same meaning as Cheikh in Arabic: spiritual guide. I am not sure why Kara is known as a Serigne and Thioune as a Cheikh. When I asked disciples, they told me "parce que c'est comme ça" - because that is just the way it is. Often, the terms may be interchanged; for example, the founder of the Mouride order Cheikh Amadou Bamba is often known as Serigne Touba, Touba being the Mouride holy city.

5 Often marabouts or chiefs.

6 Bamba was originally a Sufi of Qadiriyya origin.

7 These work farms had their antecedents in the pre-colonial cooperative Wolof work farms; see Ames (1959).

8 Bamba was first exiled to Gabon and later to Mauritania where he was put under the aegis of Sidiyya Baba, a Qadiriya marabout allied with the French.

9 First he was succeeded by all his brothers, and later upon their demise by his numerous sons from his many wives, and following their decease, their sons.

10 This is often referred to as "Barça ou Barzakhe" - "Barcelona or Death." This relates to the idea of seeking a better life abroad or to die trying. It implies how with so few opportunities at home, youth leave on illegal boats to Europe in hopes of finding work and a better life. Yet many do not make it and drown at sea or are eaten by sharks.

11 The CFA is the common currency of francophone West Africa.

12 Tijani marabouts are also well-known for engaging in this practice.

13 Bayart (1989) has described this process in reference to businessmen and politicians in Africa, glossing it as "chevauchement."
14 For example, in 1993, Wade was arrested and imprisoned, but later released, for his involvement in the murder of Babacar Sèye, a High Court judge, vice-président du Conseil Constitutionnel. It seems that Sèye's death indirectly allowed Wade's name to be placed on the ballot (New York Times 1993; Gaï Ramaka 2006).

15 La nouvelle limousine de Wade est arrivée à Dakar. Dans cette période de vaches maigres, le luxe ne passe pas inaperçu, et quel que puisse être l'origine. Surtout quand il a été constaté du côté du président de la République, qui a appelé à la solidarité nationale, il n'y a pas longtemps.

(Wade's new limo has arrived in Dakar. In this period of austerity, luxury does not go unnoticed, whatever may be the origin. Especially, when concerning the president who called for national solidarity not long ago). Author's translation.

El Malick Seck, who wrote this story, was arrested and taken to the DIC - Criminal Investigations Division; his computer and other personal effects were seized.

16 For example, construction of a causeway was started by the sea, costing millions of dollars. As the causeway had been erroneously built below sea level, the project had to be abandoned, as sea water began to seep in. Several more months and millions of dollars were invested as those responsible attempted to resolve the problem. Eventually, they realised that the problem had no solution.

17 The press (Le Quotidien, 1 June 2006, Le Monde Diplomatique - Paris, 21 May 2008) and those who share the same opinion assume GDC was a means for Karim Wade to accumulate lucre for himself and his friends in building companies. Following Abdoulaye Wade's defeat by Macky Sall in the 2012 presidential elections, Karim Wade was charged with corruption for illegally amassing capital (Reuters 2013). In 2015, Karim Wade was sentenced to six years' imprisonment, receiving an injunction demanding he pay a fine of USD $\$ 228$ million.

18 Dhikr is an Islamic devotional act involving the chanting of God's names silently or out loud.

19 As was mentioned in the introduction, they always appear garbed in a boubou, often with the kufi, a brimless, round skullcap worn by Muslim men in West Africa.

20 Diop $(2000,167)$ writes about "l'apparition d'une nouvelle génération de marabouts, celle des "marabouts mondains " qui, contrairement aux chefs soufis, sont plus préoccupés par le commerce et la politique" (The appearance of a new generation of marabouts, those worldly marabouts who in contradistinction to Sufi chiefs are engaged in commerce and politics). Author's translation.

21 Cheikh Amadou Bamba was notoriously unconcerned with capital, supposedly storing monetary oblations in an unused bathtub.

22 Daaras are traditionally qur'anic schools where disciples learn Arabic, but they often contain fields where talibés can farm as an alternative form of worship to qur'anic studies.

23 The head of Dakar police, himself a Mouride disciple, informed me that many youth are unemployed and resort to drug dealing, robbery, prostitution and even pedophilia to feed themselves and their families. Unemployment benefits do not exist in Senegal; hence, working on a daara is a means of escaping involvement in illegal activity and surviving. 
24 Serigne Saliou was head of the Mourides during my time in the field. He has since passed away and has been succeeded by various other marabouts.

25 These events happened after the death of Serigne Saliou, following Wade's failure to win the election in 2012.

26 Four is the number of wives usually condoned in Senegal.

27 Serigne Saliou was initially replaced by Cheikh Mouhammadou Lamin Bara Falilou. Upon his death in 2010, he was succeeded by Serigne Sidy Mokhtar Mbacké.

28 The Mbacké family are those descended from the founder of the order, Amadou Bamba Mbacké. His heirs now lead the Mouride order.

29 Not to be confused with the appellation Cheikh, which refers to a Muslim leader, italicised in this article for purposes of clarity.

30 Hadiya is a religious offering to one's marabout, usually consisting of money, but other items may also be offered. Pecunious disciples and politicians claiming allegiance - or wanting favours, such as disciples' votes - have been known to offer cars, houses and more.

31 See note 10.

32 Toubabs refers to white people - tourists in this context.

Dr. Kate Kingsbury, Anthropology Department, University of Alberta, Edmonton, Alberta. E-mail: kingsbur@ualberta.ca.

\section{Acknowledgements}

My deepest thanks go to Professors Andrew and Harriet Lyons, whose desire to hear about the youth of Dakar and whose unwavering belief in the importance of my work were the impetus for this article.

\section{References}

Abbink, Jon, and Inneke van Kessel (eds). 2005. Vanguard or Vandals: Youth Politics and Conflict in Africa. Leiden: Brill.

Ames, David. W. 1959. "Wolof Co-operative Work Groups.” In Continuity and Change in African Cultures, ed. W.R. Bascom and M.J. Herskovits, 224-237. Chicago: University of Chicago Press.

Argenti, Nicolas, and Alex de Waal (eds). 2002. Young Africa: Realising the Rights of Children and Youth. Trenton, NJ: Africa World Press.

Bayart, Jean-François. 1989. L'État en Afrique: La politique du ventre. Paris: Fayard.

Berliner, David. 2005. "An Impossible Transmission: Youth Religious Memories in Guinea-Conakry." American Ethnologist 32(4): 576-592. https://doi.org/10.1525/ ae.2005.32.4.576.

Brandewie, Ernest. 1971. "The Place of the Big Man in Traditional Hagen Society in the Central Highlands of New Guinea." Ethnology 10: 194-210. https://doi. org/10.2307/3773009.

Buggenhagen, Beth. 2012. Muslim Families in Global Senegal: Money Takes Care of Shame. Bloomington: Indiana University Press.

Chatterji, Manas, and Partha Gangopadhyay. 2009. Peace Science: Theory, Methods and Cases. Bingley, UK: Emerald.
Chernoff, John. 2003. Hustling Is Not Stealing: Stories of an African Bar Girl. Chicago: University of Chicago Press.

Christiansen, Catrine, Mats Utas, and Henrik Vigh (eds). 2006. Navigating Youth, Generating Adulthood: Social Becoming in an African Context. Uppsala, Sweden: Nordic Africa Institute.

Cole, Jennifer. 2007. "Fresh Contact in Tamatave, Madagascar: Sex, Money, and Intergenerational Transformation." In Generations and Globalization: Youth, Age, and Family in the New World Economy, ed. Cole, Jennifer and Deborah Durham, 74-102. Bloomington: Indiana University Press.

Comaroff, John, and Jean Comaroff. 2006. Law and Disorder in the Postcolony. Chicago: University of Chicago Press.

Copans, Jean. 1989. Les marabouts de l'Arachide: La confrérie mouride et les paysans du Sénégal. Paris: L'Harmattan.

Coulibaly, Abdou-Latif. 2003. Wade, un opposant au pouvoir: L'alternance piégée? Dakar, Senegal: Les Éditions Sentinelles.

Coulon, Christian. 1981. Le marabout et le prince: Islam et pouvoir au Sénégal. Paris: Pedone.

Cruise O'Brien, Donal B. 1971. The Mourides of Senegal: The Political and Economic Organization of an Islamic Order. Oxford: Clarendon.

- 2003. Symbolic Confrontations: Muslims Imagining the State in Africa. London: Hurst.

Cruise O'Brien, Donal B., and Christian Coulon. 1988. Charisma and Brotherhood in African Islam. Oxford: Clarendon.

Dakaractu. 2016. "Magak 2016: L’arrivée de près de 5000 boeufs à Dianatou Mahwa chez Cheikh Béthio Thioune (Images)." 17 November. https://www.dakaractu.com/MAGAL-2016-L-arrivee-de-pres-de-5000-boeufs-a-DianatouMahwa-chez-Cheikh-Bethio-Thioune-IMAGES_a121869. html.

Dakarmidi. 2017. "Exclusif dakarmidi - Coup de fil de S.E. Macky Sall à Cheikh Béthio Thioune: La paz de los valientes." 17 January. Accessed 5 September 2018. https://www. dakarmidi.net/actualite/exclusif-dakarmidi-coup-de-fil-de-s-emacky-sall-a-cheikh-bethio-thioune-paz-de-los-valientes/.

Diop, Abdoulaye-Bara. 2000. "The Senegalese Murid Trade Diaspora and the Making of a Vernacular Cosmopolitanism.” Public Culture 12(3): 679-702. https://doi. org/10.1215/08992363-12-3-679.

Diouf, Mamadou. 1996. "Urban Youth and Senegalese Politics: Dakar, 1988-1994.” Public Culture 8(2): 225-248. https:// doi.org/10.1215/08992363-8-2-225.

El-Zein, Abdul Hamid. 1977. "Beyond Ideology and Theology: The Search for the Anthropology of Islam." Annual Review of Anthropology 6: 227-254. https://doi.org/10.1146/ annurev.an.06.100177.001303.

Gaï Ramaka, Joseph (director). 2006. Et si Latif avait raison! DVD. L'Observatoire Internationale sur les libertés.

Gaye, Mandiaye. 2010. Le Sénégal sous Abdoulaye Wade: Banqueroute, corruption et liberticide. Paris: Éditions l'Harmattan.

Geertz, Clifford. 1973. The Interpretation of Cultures: Selected Essays. New York: Basic Books.

Hill, Joseph. 2007. "Divine Knowledge and Islamic Authority: Religious Specialization among Disciples of Baay Nas." PhD dissertation, Yale University. 
Honwana, Alcinda. 2012. The Time of Youth: Work, Social Change and Politics in Africa. Sterling, VA: Kumarian.

Honwana, Alcinda, and Filip De Boeck (eds). 2005. Makers and Breakers: Children and Youth in Postcolonial Africa. Oxford, UK: James Currey.

Janson, Marloes. 2014. Islam, Youth, and Modernity in the Gambia: The Tablighi Jama'at'. Cambridge: Cambridge University Press/International African Library.

Kagwanja, Peter. 2004. "The Clash of Generations? Youth Identity, Ethnic Violence and the Politics of Moi Succession, 1991-2002." In Vanguard or Vandals? Youth, Politics and Conflict in Africa, ed. J. Abbink and W. van Kessel, 81-109. Leiden: Brill Academic.

Kingsbury, Kate. 2014. "New Mouride Movements in Dakar and the Diaspora." DPhil thesis, University of Oxford.

Lonsdale, John. 1987. "La pensée politique des Kikuyu et les idéologies du Mau-mau." Cahiers d'études africaines 27: 329-357. https://doi.org/10.3406/cea.1987.3409.

Lyons, Andrew, and Harriet D. Lyons. 1987. "Magical Medicine on Television: Benin City, Nigeria." Journal of Ritual Studies 1(1): 103-136. http://www.jstor.org/stable/44368322.

Masquelier, Adeline, and Soares, Ben. 2016. Muslim Youth and the 9/11 Generation. Santa Fe, NM: School for Advanced Research Press.

Mauss, Marcel. 1969. The Gift: Forms and Functions of Exchange in Archaic Societies. London: Routledge.

Mbembe, Achille. 1992. "Provisional Notes on the Postcolony." Africa 62(1): 3-37. https://doi.org/10.2307/1160062. . 2001. On the Postcolony. Berkeley: University of California Press.
Meyer, Birgit. 1998. "Make a Complete Break with the Past: Memory and Post-Colonial Modernity in Ghanaian Pentecostalist Discourse." Journal of Religion in Africa 28(3): 316-349. https://doi.org/10.1163/157006698x00044.

New York Times. 1993. "Senegal Releases 4 Men Held in Killing of Election Official.” 19 May. https://www.nytimes. com/1993/05/19/world/senegal-releases-4-men-held-in-killing-of-election-official.html.

Reuters. 2013. "Son of Senegal's Ex-President Charged with Corruption.” 17 April. https://www.reuters.com/article/ us-senegal-corruption-wade/son-of-senegals-ex-presidentcharged-with-corruption-idUSBRE93G11020130417.

Seck, Mamadou. 2005. Les scandales politiques sous la présidence de Abdoulaye Wade: Vers un nouveau modèle d'étude en Afrique: La scandalogie. Paris: Editions L'Harmattan.

Soares, Benjamin F., and René Otayek. 2007. Islam and Muslim Politics in Africa. New York: Palgrave Macmillan.

Thomson, Alistair, and Nick Tattersall. 2007. "Worst Riots in Years hit Senegalese Capital.” Reuters, 21 November. https:/www.reuters.com/article/us-senegalprotests/worst-riots-in-years-hit-senegalese-capitalidUSL211189220071121.

U.S. Department of State. 2007. Country Reports on Human Rights Practices for 200\%. https://www.state.gov/j/drl/rls/ hrrpt/2007/.

Worsley, Peter. 1957. The Trumpet Shall Sound. London: Macgibbon \& Kee. 